\title{
Keeping the middle path: mainstreaming religious moderation through Islamic higher education institutions in Indonesia
}

\author{
Muhammad Nasir \\ Universitas Islam Negeri Sultan Aji Muhammad Idris Samarinda \\ E-mail:muhammadnasir@iain-samarinda.ac.id \\ Muhammad Khairul Rijal \\ Universitas Islam Negeri Sultan Aji Muhammad Idris Samarinda \\ E-mail: rijalforza@gmail.com \\ DOI:10.18326/ijims.v11i2.213-241
}

\begin{abstract}
The Ministry of Religious Affairs of Indonesia continues to voice religious moderation to mainstream a peaceful Islamic discourse. This article aims at looking at religious moderation values from several Islamic higher education institutions in Indonesia. The focus of article aims to find a pattern of the implementation of moderation in Islam in Islamic universities. It discusses to what extent Islamic higher education institutions internalize religious moderation values to students. By conducting qualitative research, this article explores 3 Islamic higher education institutions in Indonesia: Universitas Islam Negeri Maulana Malik Ibrahim, Universitas Darussalam Gontor Ponorogo, and Ma'had Aly As'adiyah. The result shows that higher education institutions play a critical role in inculcating religious moderation values through pesantren institutions. The
\end{abstract}


Pesantren universities have a role in transmitting moderate Islamic values through their curriculum and various religious activities. This research reveals that religious moderation is implicated in these 3 Islamic universities. The curriculum is eclectic and reflects moderation values, such as national commitment, tolerance, non-violence, and local culture accommodation. This study concludes that the three pesantren universities in Indonesia have a distinctive pattern of emphasizing moderation in the three areas: theoretical, practical, and ideological aspect.

Artikel ini bertujuan untuk melihat nilai-nilai moderasi beragama dari beberapa perguruan tinggi keagamaan Islam. Fokus artikel ini ditujukan pada pencarian pola moderasi beragama pada tiga universitas bermodel pesantren. Wacana moderasi beragama akhir-akhir ini terus disuarakan oleh Kementerian Agama sebagai upaya dalam pengarusutamaan wacana keislaman yang damai. Artikel ini menghadirkan diskusi mengenai sejauh mana lembaga Pendidikan tinggi Islam melakukan internalisasi nilai-nilai moderasi dalam beragama kepada para mahasiswa. Melalui penelitian kualitatif, artikel ini menelusuri objek di tiga perguruan tinggi Islam: Universitas Maulana Malik Ibrahim Malang, Universitas Darussalam Gontor Ponorogo, dan Universitas As'adiyah Sengkang. Artikel ini menemukan bahwa Lembaga Pendidikan tinggi memiliki peran penting dalam menanamkan nilai-nilai moderasi beragama melalui Lembaga tradisional pesantren. Pesantren-pesantren kampus berperan mentransmisikan nilai-nilai keislaman yang moderat melalui kurikulumnya dan berbagai kegiatankegiatan keagamaan yang lain. Hasil penelitian ini meneguhkan bahwa moderasi beragama terlihat melalui kurikulum yang dijalankan di tiga universitas Islam ini. Kurikulum tersebut bersifat eklektik dan mencerminkan nilai-nilai moderasi seperti komitmen kebangsaan, toleransi, anti kekerasan, dan akomodatif terhadap kebudayaan lokal. Hasil penelitian ini menyimpulkan bahwa ketiga pesantren kampus di Indonesia memiliki pola penekanan moderasi yang khas dalam tiga bidang: teoritis, pratis dan ideologis.

Keywords: Religious moderation; Islamic higher education institution; pesantren university; Multiculturalism 


\section{Introduction}

This article discusses the development of Islamic moderation values in several Islamic higher education institutions through pesantren university. The significance of this article lies in three crucial issues. The crucial issues are moderation as a religious attitude, the Islamic higher education institution as a forum for producing Muslim scholars, and pesantren university as a strategy for higher education managers to transmit Islamic values. These three issues have interplay and form a system projected to change or maintain Islamic diversity in Indonesia, known for its moderate condition. Islam in Indonesia is allegedly able to negotiate dogmatic religious values based on relative liberalism and multiculturalism. Different religious education institutions continue to thrive in Indonesia. However, the Muslim community publicly campaigns for Islam with high enthusiasm for preaching. Hence, the Indonesian Muslim community has moderate Islamic characteristics, specifically in the middle path between radical fundamentalists and liberals.

Several studies related to religious moderation are aimed at proving that Islam upholds religious moderation, tolerance, peace, and rejects being labeled as a terrorist religion. These Muslim Americans continue to use their civil rights to prove that they are both good American citizens and devout Muslims. This condition has undoubtedly become the umpteenth time pressure for the Muslim community after the world war and cold war. ${ }^{1}$

For decades, Islamic moderation has been a mainstream discourse in Islamic studies. Moderation is an appropriate term that describes the real Islam and negates some of the Muslim societies' realities of violent acts

${ }^{1}$ Rachel M Gillum, Muslims in a Post-9/11 America, Michigan: University of Michigan Press, 2018; Theodore Gabriel and Jane Idleman Smith, Islam and the West Post 9/11, London: Routledge, 2017; Chintamani Mahapatra, The US Approach to the Islamic World in Post-9/11 Era: Implications for India, New Delhi, Academic Foundation, 2009. $\{\backslash \backslash \mathrm{i}\{\}$ Muslims in a Post-9/11 America\} (Michigan: University of Michigan Press, 2018 
in the name of religion. Moreover, moderation is often used to interpret a popular word found in the Quran, wasatiyyah. The word wassatiyah or moderation in Islam is terminologically used as a theoretical and practical concept in several Muslim countries, particularly in Southeast Asia, such as Indonesia, Malaysia, and Brunei Darussalam. Theoretically, it is often used as lecture material by scholars to describe Islam. The wasatiyyah concept is used as a guide for policymakers to counter the narrative of Islamic terrorism. ${ }^{2}$ However, some scholars have responded critically to this Islamic moderation discourse. Islamic moderation rejects the reality that there is a robust Islamic dogma in society. Reaffirming the moderation concept makes Islamic discourse become monolithic essence. People pinpoint that real Islam is moderate Islam; otherwise, it is not Islam. ${ }^{3}$

${ }^{2}$ Mohammad Hashim Kamali, The Middle Path of Moderation in Islam: The Qur'anic Principle of Wasatiyyah, Oxford: Oxford University Press, 2015; Timothy P. Daniels, Sharia Dynamics: Islamic Law and Sociopolitical Processes, Switzerland: Palgrave MacMillan, Springer, 2017, 145; Mohd Mizan Aslam and Rohan Gunaratna, Terrorist Rehabilitation and Community Engagement in Malaysia and Southeast Asia, London: Routledge, 2019.

${ }^{3}$ Nuraan Davids, "Islam, Moderation, Radicalism, and Justly Balanced Communities," Journal of Muslim Minority Affairs, Volume 37, No. 3 (2017), 309-320then the way to counter "radical" Islam is through "moderate" Islam. Seemingly, "moderate" Islam is that which "radical" Islam is not. In appointing "moderate" Islam as an antidote to "radical" Islam, the implication is that, conceptually at least, the two terms are contradistinctive. Yet, while much is, perceivably, known about "radical" Islam, with its associated ills of an unequivocal Islamic worldview, very little attention has been afforded to this signifier, "moderate". Inasmuch as this term is bandied around, even scholars of Islam will acknowledge that, within Islamic education, understandings of and debates on conceptions of moderation, and moderate Muslim communities, have been somewhat overlooked. What, therefore, is a "moderate" Islam? What is a "moderate" Muslim community and how would it act? What are the implications for a "moderate" community in relation to pluralist societies? And, can such a "moderate" community offer a practical response not only to "radical" Islam, but, perhaps, more importantly, to increasingly antagonistic, liberal contexts?","container-title":"Journal of Muslim Minority Affairs","DOI":"10.1080/13602004.2017.1384672","ISSN":"1360-2004","is sue":"3","note":"publisher: Routledge \n_eprint: https://doi.org/10.1080/13602004.2017. 1384672","page":"309-320","source":"Taylor and Francis+NEJM","title":"Islam, Moderation, Radicalism, and Justly Balanced Communities","volume":"37","author":[\{"family":"Davids","g iven":"Nuraan"\}],"issued":\{"date-parts":[["2017",7,3]]\}\}\}],"schema":"https://github.com/citationstyle-language/schema/raw/master/csl-citation.json"\} . 
Moderation in Islam continues to be voiced in Indonesia as a relevant concept for religious and national discourse. Religious moderation is noticeably appropriated with modern multicultural political conditions. Therefore, Indonesia brings moderation discourse through state religious institutions like The Ministry of Religious Affairs and higher education institutions. These institutions serve as a place for Muslim scholars to be involved in various fields of life. The inculcation of Islamic moderation values enables scholars to be flexible in applying Islamic teachings in line with their field of study, without departing from the basic religious principles.

Pesantren have played an essential role in the education system history in Indonesia. Pesantren has existed long before the inception of formal schools. Today, hundreds of years into its existence, pesantren have never disappeared from Indonesia's educational realm. Therefore, even though it is still traditional, pesantrens are still considered relevant to Indonesia's modern education system. Pesantrens nowadays continue to receive state support through the Ministry of Religious Affairs to develop and respond to people's Islamic religious education needs. In some cases, the government requires Pesantren's standardization for its compatibility with its curriculum. ${ }^{4}$ Thus, Islamic higher education institutions implement a pesantren system for some students to internalize Islamic values.

In Indonesia, pesantren university are often termed Ma'had Al-Jamiah. Pesantren university in several higher education institutions has a strategic position. Apart from being a distinguishing feature from other public universities, Pesantren university significantly contributes to fosters students. Furthermore, it enhances the academic culture in the institution's environment. Pesantren universities are expected to strengthen students' religious basics and foreign language skills, both Arabic and English. It is

\footnotetext{
${ }^{4}$ Florian Pohl, Islamic Education, and the Public Sphere, Gottingen: Waxmann Verlag, 2009.
} 
also a place for fostering religious activities, such as tahsin qiraah Al-quran (improving Quran alliterate) and tahfiz Al-quran (memorizing the Quran) and developing various other practical religious skills.

The organizing process of Pesantren university is developed innovatively and creatively by empowering all available resources. Pesantren university, an extension of internalizing religious values in higher education institutions, must be the beacon of quality student development with a global perspective. Therefore, students adapt to the current global changes. The pesantren university should achieve this condition without reducing their idealism and orientation as an Islamic institution. ${ }^{5}$

Student coaching at Pesantren university needs to be in line with national education goals if it has a clear and measurable roadmap. The curriculum is one of the tools used to achieve educational goals. It is a guide in the implementation of learning at all education levels. Therefore, this article examines two critical keywords in the learning process in pesantren university, specifically the curriculum and teaching and inculcating worship values combined with religious moderation narratives. Therefore, several research questions emerge on how Islamic higher education institutions in Indonesia instill religious moderation values? What are the curriculum characteristics in various pesantren universities that are in line with the religious moderation principle? Moreover, to what extent did Islamic higher education institutions internalize the Islamic moderation values to students through pesantren university?

Some scholars have conducted several studies on Islamic education, pesantren, and moderation in Islam. This paragraph will highlight those studies as a literature review highlighting their significance and relevance with earlier discussion. A study of Islamic education, pesantren occupies

${ }^{5}$ Babun Suharto, Dari Pesantren Untuk Umat: Reinventing Eksitensi Pesantren Di Era Globalisasi, Surabaya: Imtiyaz, 2011, 85. 
its role as a traditional education system that continuously develops from time to time. Firdaus Wajdi argued that the globalization stream brings the contemporary development of pesantren. Globalization makes pesantren wellbeing connected with the secular education system. Therefore, pesantren also widely creates global networking. One of the determinants in the meeting between the Islamic traditional education system and the general education system is the university. ${ }^{6}$ Lukens-Bull argued that education should manifest several correct moral values theoretically. At the same time, education has been a central component of modernization in Indonesia. Besides, Islamic education institution systems like pesantrens in Indonesia try to redefine modernity for producing the graduate as a representative of Islamic values. ${ }^{7}$ Pam Nilan also studies the core value and spirit of Islamic Education. According to Nilan, Pesantren in Indonesia instills a far-reaching spirit of education. Even the world runs on a globalized and modern rule, the spirit of education in many pesantrens is understood to reflect nothing less than the will of God. ${ }^{8}$

In another part, the studies on moderation in Islam are conducted separately from university and pesantren issues. Muhammad Zuhdi discusses how Islamic education in Indonesia has been created to define moderate Islam, but, at the same time, faces some challenges that have a goal to turn religious education into conservative religious doctrines. According to Zuhdi, the way religion is presented in school influences how Indonesians view and practice religion. It is a problem that should

${ }^{6}$ Firdaus Wajdi, "Pesantren and University: An Educational Networking in the Era of Globalization", Proceeding, International Conference on Social Science and Humanities in the Era of Market Globalization, Jakarta, 2018, Universitas Negeri Jakarta.

${ }^{7}$ Ronald Lukens-Bull, "Teaching Morality: Javanese Islamic Education in a Globalizing Era”, Journal of Arabic and Islamic Studies, Vol. 3, No. 1 (2000), 26-48.

"Pam Nilan, "The Spirit of Education in Indonesian Pesantren," British Journal of Sociology of Education, Volume 30, No. 2 (2009), 219-232. 
be faced by moderate Islam to minimize the contra-effort by a conservative interpretation of Islam. While the government attempts to minimize the influence of conservative interpretations through the official religious education curriculum, some Islamic schools (particularly private Islamic education institutions) might constitute their curriculum.

From the several studies mentioned, there is a lack of studies concerning how Islamic education, Islamic universities (as higher Islamic education institutions), and the discourse of Islamic moderation are dynamically interplayed in holistic studies. Therefore, this article tries to overcome the research vacuity that is conducted by earlier studies. This article will map a pattern of Islamic moderation constituted by the three Islamic higher education institutions. The moderation pattern in Islam is derived from four religious moderation indicators formulated officially by the Ministry of Religious Affairs. These indicators are the commitment of nationality, tolerance, anti-violence, and being accommodative to local culture.

This article is a fieldwork research, the object of which is taken from 3 higher education institutions, including Universitas Darussalam Gontor (hereafter called UNIDA) in Ponorogo, Ma'had Aly As'adiyah Sengkang, Wajo South Sulawesi, and Ma'had aljämi'ah Universitas Islam Negeri Maulana Malik Ibrahim Malang (hereafter called UIN Maliki Malang). The selection of these three different pesantren universities has logical arguments. UNIDA Gontor represents a modernity movement of pesantren because it encompasses the four main components in education management. These components are a mosque, Kiai (scholar) and ustadz (teacher), student dormitories, and academic activities. Ma'had Aly As'adiyah Sengkang was chosen because it is one of the prominent Pesantren in Indonesia, from which many alumni have graduated. Several alumni have succeeded in establishing Islamic boarding schools in various provinces throughout Indonesia. Pesantren is the primary school established by an alumnus. The 
center-branch is a moral-emotional attachment, including the system and religious understanding adopted. This network is extensive and robust, covering branches spread across various regions.

Meanwhile, UIN Maliki Malang is a representation of State Islamic higher education institution. The Ma'had Al-Jami'ah is managed by the State Islamic University, which is considered by most to be the direction of pesantren university. Several students, pesantren managers, and teaching staff were involved in the in-depth interview process. According to the relevant theory, this article resulted from a qualitative analysis process by connecting one variable to another. Finally, the results of this analysis provide answers to the research questions raised.

\section{Conceptualization of moderation in Islam}

Islam, as a considerable religion in Indonesia, is the object mainly related to religious moderation. Consequently, various concepts and terms emerged as a form of contextualization of religious moderation theories, such as Islamic moderation, moderate Islam, and moderate Muslim. The term 'Islamic moderation' was allegedly coined by Muslim scholars and amplified by various media after 1979 Iranian Revolution. Islamic moderation comes in the landscape of identity communication, which is the relationship between Muslims and the west. ${ }^{9}$ Various parties have then used the term 'moderate' instead of identifying Muslims as being adaptive to reform in modern countries. ${ }^{10}$

\footnotetext{
${ }^{9}$ Tazul Islam and Amina Khatun, "Islamic Moderation in Perspectives: A Comparison Between Oriental and Occidental Scholarships," International Journal of Nusantara Islam, Volume 3, No. 2 (2015), 69-78.

${ }^{10}$ Kamali, The Middle Path of Moderation in Islam...; Nuraan Davids, "Islam, Moderation leading Islamic law expert Mohammad Hashim Kamali examines the concept of wasatiyyah, or moderation, arguing that scholars, religious communities, and policy circles alike must have access to this governing principle that drives the silent majority of Muslims, rather than focusing on the extremist fringe. Kamali explores wasatiyyah in both historical/conceptual terms and in contemporary/practical terms. Tracing the definition and scope of the concept from the
} 


\section{Muslim scholars often start the discussion of Islamic moderation from} a Quranic verse in Surah al-Baqarah verse 143. The word wasatan in this verse is the developed into wasatiyah, a term narrated as the normative basis for the necessity of religious moderation in Islam. This wasatiyyah is an attitude that has relational essence with al'-adl (justice and balance),

foundational sources of Islam, the Qu'ran and Hadith, he demonstrates that wasatiyyah has a long and well-developed history in Islamic law and applies the concept to contemporary issues of global policy, such as justice, women's rights, environmental and financial balance, and globalization. Framing his work as an open dialogue against a now-decades long formulation of the arguably destructive Huntingtonian \"clash of civilizations \" thesis as well as the public rhetoric of fear of Muslim extremism since the attacks of September 11, 2001, Kamali connects historical conceptions of wasatiyyah to the themes of state and international law, governance, and cultural maladies in the Muslim world and beyond. Both a descriptive and prescriptive meditation on a key but often neglected principle of Islam, The Middle Path of Moderation in Islam provides insight into an idea that is in the strategic interest of the West both to show and practice for themselves and to recognize in Muslim countries.","ISBN":"9780-19-022684-8","language":"en","number-of-pages":"337","publisher":"Oxford University Press","source":"Google Books","title":"The Middle Path of Moderation in Islam: The Qur'anic Principle of Wasatiyyah","title-short":"The Middle Path of Moderation in Islam","a uthor":[\{"family":"Kamali","given":"Mohammad Hashim"\}],"issued":\{"date-parts":[["2015",5,18] ]\}\}\},\{"id":1314,"uris":["http://zotero.org/users/3585373/items/VSCTRMW6"],"uri":["http:// zotero.org/users/3585373/items/VSCTRMW6"],"itemData":\{"id":1314,"type":"articlejournal","abstract":"If media outlets and political rhetoric are to be believed, then the way to counter "radical" Islam is through "moderate" Islam. Seemingly, "moderate" Islam is that which "radical" Islam is not. In appointing "moderate" Islam as an antidote to "radical" Islam, the implication is that, conceptually at least, the two terms are contradistinctive. Yet, while much is, perceivably, known about "radical" Islam, with its associated ills of an unequivocal Islamic worldview, very little attention has been afforded to this signifier, "moderate". Inasmuch as this term is bandied around, even scholars of Islam will acknowledge that, within Islamic education, understandings of and debates on conceptions of moderation, and moderate Muslim communities, have been somewhat overlooked. What, therefore, is a "moderate" Islam? What is a "moderate" Muslim community and how would it act? What are the implications for a "moderate" community in relation to pluralist societies? And, can such a "moderate" community offer a practical response not only to "radical" Islam, but, perhaps, more importantly, to increasingly antagonistic, liberal contexts?","container-title":"Journal of Muslim Minority Affairs","DOI":"10.1080/13602004.2017.1384672","ISSN":"1360-2004","is sue":"3","note":"publisher: Routledge\n_eprint: https://doi.org/10.1080/13602004.2017. 1384672","page":"309-320","source":"Taylor and Francis+NEJM","title":"Islam, Moderation, Radicalism, and Justly Balanced Communities","volume":"37","author":[\{"family":"Davids","g iven":"Nuraan"\}],"issued":\{"date-parts":[["2017",7,3]]\}\}\}],"schema":"https://github.com/citationstyle-language/schema/raw/master/csl-citation.json"\} ... 
al-fadl (excellence), and al-bainiyyah (median). ${ }^{11}$ Islamic moderation needs to be applied with in-depth knowledge and a generous attitude towards religion. Therefore, the important thing in Islamic moderation is a fair attitude and prudence in religious actions, such as in worship. ${ }^{12}$

This 'middle path' concept has implications for various religious dimensions, including rituals, thoughts, and political behavior. Determining whether someone is moderate or not in terms of ritual worship needs more academic discussion. Moderation identification may be performed by classifying religious thoughts. Scholars have already conducted this classification. In Islam, various thought schools grew at dawn since the early years after the passing of Prophet Muhammad.

According to the taxonomy of Islam, moderate Islam is the intermediary between Islamist ideology and Islam's indifference. Although Islam should be used as a fundamental value in life, a Muslim must be flexible in responding to things that do not have explicit norms in the Quran and Hadith. Therefore, a moderate attitude should always be manifested in religious behavior. ${ }^{13}$

This article has a weakness in determining the terminology between religious moderation (in general) and Islamic moderation (in particular). As an academic discourse, the term religious moderation is more general for discussion than Islamic moderation. However, this research took material objects from several Islamic higher education institutions for discussion, specifically Islamic moderation. Therefore, this article appears to have a terminology inconsistency between 'religious moderation' and 'Islamic moderation.' Overcoming this inconsistency, the authors assert

${ }^{11}$ Ali Muhammad Sallabi, Al-Wasat\}iyyah fi al-Qur'>an al-Kari>m, Oman: Dar an-Nafais, 1999.

${ }^{12}$ Quraish Shihab, Tafsir Al-Mishbah: Pesan, Kesan dan Keserasian al-Qur'an, volume 1, Tangerang: Lentera Hati, 2000.

${ }^{13}$ Nazih Ayubi, Political Islam: Religion and Politics in the Arab World, London: Routledge, 2003. 
that religious moderation is the core substance of academic discourse. This paragraph does not discuss too much on moderate Islam as a general discourse due to terminological complexity.

In the pre-independence era, Muhammadiyah and Nahdlatul Ulama (NU) were established with a moderate religious concept. Amid sociopolitical-cultural modernization brought by the colonial group, and the strong opposition to colonial culture from some Muslim elements, several Muslim groups tried to stand in the middle of these two currents. Therefore, Muhammadiyah and NU are milestones of Islamic moderation in the modern era. The values of moderation and progressiveness in these two Islamic mass organizations are reflected in fields like theology, education, social, politics, culture, and economy. ${ }^{14}$

Some scholars in Indonesia have conducted theoretical studies on religious moderation. Moderatism is a conceptual term that is sufficiently hard to be defined. This term is always highly contested for its meaning, both among internal Muslims and outsiders. Moderate Islam representation is pinned to two organizations, Muhammadiyah and NU. Moderation in Islam needs more academic discussion from within by bringing common denominators, such as Pancasila and Undang-Undang Dasar Negara Republik Indonesia 1945 (UDNRI 1945, Indonesian constitution) as cultural symbols conveying moderation messages. Therefore, Islamic moderation practice should be implemented through Indonesia's formal educational institutions affiliated with Muhammadiyah and NU. ${ }^{15}$

\footnotetext{
${ }^{14}$ Haedar Nashir, Understanding the Ideology of Muhammadiyah, Surakarta: Muhammadiyah University Press, 2015; Zuly Qodir, Muhammadiyah Studies: Reorientasi Gerakan dan Pemikiran Abad Kedua, Yogyakarta: Kanisius, 2010; Greg Fealy and Greg Barton, Nahdlatul Ulama, Traditional Islam and Modernity in Indonesia, Monash: Monash Asia Institute, Monash University, 1996; Muchotob Hamzah and et.al, "Pengantar Studi Aswaja An-Nahdliyah," in Pengantar Studi Aswaja An-Nahdliyah, Yogyakarta: LKiS Pelangi Aksara, 2017.

${ }^{15}$ Masdar Hilmy, "Quo-Vadis Islam Moderat Indonesia? Menimbang Kembali Modernisme Nahdlatul Ulama Dan Muhammadiyah," MIQOT: Jurnal Ilmu-Ilmu Keislaman, Volume 36, Number 2 (2012), 262-281.
} 
As both a conceptual framework and a practical idea, moderation in Islam has only been popularized in the last half-decade by the Ministry of Religious Affairs. Ultimately, the idea of developing a conceptual framework for religious moderation is codified in a special book published by the Ministry Religious Affairs.

Through the Religious Moderation reference book, the meaning of moderation in Islam is conceptualized in a measured manner. The basic principle of moderation lies in the attitudes of 'balance' and 'justice.' These two attitudes are easily formed when religious people have three important characters, including wisdom, purity, and courage. A moderate attitude in Islam is easily manifested when a person has extensive religious knowledge and acts wisely, they resist temptation sincerely, and they acknowledge the existence of other interpretations as long as they are in line with wise values.

The Ministry of Religious Affairs simplifies these indicators into four factors that align with Indonesia's religious nature and nationality. The four indicators are national commitment, tolerance, anti-violence, and being accommodating to local culture. National commitment helps examine the extent to which a person's perspective and attitude influence loyalty to the necessary consensus of nationality. Tolerance refers to being open, generous, voluntary, and acceptant of differences. Tolerance is an essential foundation in a multicultural country like Indonesia. A person's acceptance of differences outside of themselves is the key to peace for a democratic and multicultural country. Violence in a religious moderation context is an ideology and an understanding through which people want to make changes to the social and political system instantly in the name of religion. Violence can be in verbal, physical, and mental forms. The next indicator is adaptive to local culture. This attitude is used to see the extent of the willingness to accept religious practices that accommodate local culture and traditions. Moderate people tend to be friendlier in 
accepting local traditions and culture in their religious behavior if they do not oppose the central religious teachings. ${ }^{16}$

The strategy to enhance a religious moderation value at the university level involves several pesantren universities or Mahad al-Jami'ah. The pesantren university is considered an appropriate institution for instilling religious moderation values because it directly contacts students who focus on religious activities. Although pesantren university management models and patterns differ from one university to another, its function in instilling religious moderation tends to have the same urgency. The pesantren university is the starting point for the cultivation of moderate Islamic values for students entering the university environment.

\section{Pesantren university and its role}

Among the key elements of traditional Islam in Indonesia are pesantren institutions and Kiai personality (master teacher, ajengan, or other names depending on region). Pesantren is an environment where santri (Islamic students) live, socialize, and interact with pesantren residents, including Kiai. The Kiai is considered an exemplary figure. Kiai's mastery of classical Arabic books written by earlier scholars is a good reason they are respected. Pesantren adequately describes the traditional Islamic education in Indonesia. Pesantren still considered as the appropriate form of Islamic educational institutions to transmit Islamic values. ${ }^{17}$ Therefore, pesantren has been used by several Islamic universities as an institution to internalize Islamic values intensively. This study determines the characteristics of pesantren university by visiting several Islamic higher education institutions. Students' religious activities in pesantren university are similar to traditional

\footnotetext{
${ }^{16}$ Tim Penyusun, Moderasi Beragama, Jakarta: Badan Litbang dan Diklat Kementerian Agama RI, 2019.

${ }^{17}$ Martin van Bruinessen, Kitab Kuning, Pesantren Dan Tarekat: Tradisi-Tradisi Islam di Indonesia, Bandung: Mizan, 1995.
} 
pesantren in general. They pursue various Islamic studies through Kiai as the center of religious knowledge.

The first pesantren described in this article is Darussalam Gontor University (UNIDA). This university is under the Darussalam Gontor Modern Islamic Boarding School. Pesantren Gontor was born from an idea of the importance of modernizing an Islamic education institutional system. Pesantren Gontor was founded on Monday, September 20, 1926, to coincide with the 12th Rabi'ul Awwal $1345 \mathrm{H}$ by three prominent figures: K.H. Ahmad Sahal, K.H. Zainuddin Fannani, and K.H. Imam Zarkasyi. The educational curriculum design at Darussalam Gontor University (UNIDA) reflects Islamic Worldview. Some of the fundamental values embraced by Darussalam Gontor University (UNIDA) are five souls (sincerity, simplicity, self-reliance, ukhuwah Islamiyah, freedom).

Moreover, the Gontor motto (noble character, healthy body, broad knowledge, free-thinking) always inspire all university residents' activity. These fundamental values have a vital role in the educational process. That is why the Darussalam Gontor University (UNIDA) emphasizes education more than the teaching process. The curriculum structure of pesantren university at UNIDA Gontor strengthens spiritual and social attitudes based on Islamic teachings. Furthermore, it strengthens the ability to read, write, translate, and simultaneously practice and understand the Islamic religion's basics. The simplification of pesantren curriculum characteristics at UNIDA leads to 3 main points: knowledge integration between "general" and religious science, worldview indoctrination, and inclusivity of global association.

Ma'had Aly As'adiyah Sengkang Wajo is an Islamic religious college that aims to create graduates who are experts in Islam. In 2001, the Indonesian Minister of Religious Affairs issued decree number 284 of 2001, which confirmed Ma'had Aly's status as a high-level scholarly educational 
institution. This policy was followed by the Director-General of Islamic Guidance Number E/179/2001 regarding the main points of ma'had aly implementation guidelines as formal and informal. In the Pesantren university, in Ma'had Aly As'adiyah, Wajo Regency, South Sulawesi has its uniqueness. The santri are Ma'had Aly students with a curriculum structure similar to the undergraduate program.

Ma'had Aly has specific graduate learning outcomes that aim to strengthen four categories of goals i.e. spiritual attitudes, religious knowledge, Arabic literate, and other religious practical skills. To strengthen students' spiritual attitudes, they are always required to participate in congregational prayers actively. Strengthening knowledge and skills is carried out through several programs such as Quranic studies, learning foreign languages and reading Islamic Arabic literatures.

The Maulana Malik Ibrahim State Islamic University of Malang has a great effort in creating students with some characteristics such as broad knowledge, sharp eyesight, intelligent brain, soft heart, and enthusiasm because of God. ${ }^{18}$ Curricular, co-curricular, and extracurricular educational activities are directed at empowering students' potential and academic interests. Furthermore, graduates should be responsible for delivering Islamic values. Students are also expected to have a high spirit and to have the ability to be a role model for the surrounding community. ${ }^{19}$ The pesantren at the Maliki Malang State Islamic University consists of several mabna (building). All buildings (mabna) are occupied by new students and those that want to stay and carry out full activities at the pesantren. Some of these buildings (mabna) were given Muslim scholar figures, such as al-Ghazali, Ibn Rushd, Ibn Sina, Ibn Khaldun, Al-Farabi, and Ar-Razi.

\footnotetext{
${ }^{18}$ The Center of Ma'had Al-Jami'ah, Pedoman Akademik Mahasantri Pusat Ma'had Al-Jami'ah 2019 Universitas Islam Negeri (UIN) Maulana Malik Ibrahim (Maliki) Malang, Malang: UIN Maulana Malik Ibrahim, 2019, 1.

${ }^{19}$ The center of Ma'had Al-Jami'ah, Pedoman Akademik..., 2.
} 
The pesantren university's religious activities are developed through several excellent programs, such as teaching the Quranic studies, the primary Islamic thought taken from classical figh books, and teaching Arabic and English. Learning activities of the Quranic studies and primary Islamic thought are conducted twice a week. Foreign language learning is carried out every day with the form of vocabulary enrichment. Furthermore, the foreign language learning program is conducted regularly, both weekly, monthly, and annually.

By looking at several curriculum designs and characteristics, pesantrens in the three universities have a role in emphasizing moderation values to all students. Emphasizing moderation values could be discussed through the narrative below:

\section{Strengthening the commitment to nationality}

The three pesantrens of Islamic higher education institutions show their existence and Indonesia's history both socially and politically. Through an implemented and designed curriculum, the universities put several subjects related to the discussion of nationality. The commitment to nationality is reflected in all academicians' participation in national traditions and activities, such as Independence Day. Respect for state symbols, such as Bendera Merah Putih (the red and white flag), Garuda Pancasila, and the president, is always instilled through various activities. Legal educationsuch as discipline, introduction to Indonesia's constitution, and principal guidance of the state-is performed according to Islamic students' study program.

In a formal curriculum, the three universities provide several courses appropriate to Indonesia's national interest like Pancasila, civic education, and Bahasa Indonesia. A student in the first semester takes these courses. These courses should be internalized in a daily religious activity carried out 
by pesantren management. Student activities are in the field of the religious, academic, and national realm. A real form of these activities includes national-Islamic proselytizing, nationality discussion, flag ceremony, and commemoration of Indonesia's national day.

In some cases, the nationalism could be internalized through discipline habituation. All dormitories in the three pesantren universities are established with a set of institutional rules. A process of disciplinary culture habituation could train a student in a culture of subservience to law. From a state legal perspective, subservience to the law is one indicator that indicates a good citizen.

Another activity that becomes a means in internalizing core values of commitment to nationality is through the scouting movement. The Indonesia scout movement (Pramuka) trains students to be valuable people to serve and love their country and show patriotism and national defense spirit. In the scout movement, they are accustomed to, for instance, cheering and singing, which evokes the spirit of nationalism. Besides, the scout movement is a medium for instilling and strengthening the state's ideology to all students. The three universities' scout movement displays Indonesia's respected state symbols like bendera merah putih and Pancasila in some public institutional areas.

\section{Building tolerance}

Tolerance education is actively being carried out. Students come from various regions throughout Indonesia with different cultures, languages, and characters. They live in the same dormitory and interact with each other. The governing disciplinary rules, regardless of ethnic differences, give them the feeling of having the same struggle. The social interaction of heterogeneous communities formed from everyday struggles creates a new culture in social interaction. 
Furthermore, attitudes of mutual understanding, consideration, and a sense of inclusiveness were formed. An environment with a heterogeneous culture triggers a tolerant attitude. A very dynamic interaction creates an attitude that negotiates between one identity and another. The negotiation process among identities produces moderation values. ${ }^{20}$ However, the tolerance obtained is not from some academic theories but also the students' empirical experience. Hence, students' tolerance spirit will be drilled when they are outside campus.

Internalization of the value of tolerance is also conducted through social activity. Tolerance is faced with identity diversity and should be implemented in the form of community services. Students are habituated to having social empathy for unlucky people suffering from severe illnesses and terrible disasters.

Religious rituals also become a practice of implementation of tolerance values in pesantren university. In Unida, for instance, ritual worship has no institutional uniformity. In its long history, Islam has various interpretations based on two primary sources: Al-Quran and al-Hadith. Interpretations of these two primary sources often lead to a remarkably different argumentation (khiläfiyah). Different argumentations are represented by the emergence of several schools in Islam. Unida allowed the students to adhere to any Islamic schools if it does not contradict the principal teachings of Islam and the majority of scholars (jumhur ulamā) in the Islamic tradition.

${ }^{20}$ Zaenuddin Hudi Prasojo et. al, "Moderate Islam and the Social Construction of Multi-Ethnic Communities in the Hinterland of West Kalimantan," Indonesian Journal of Islam and Muslim Societies, Volume 9, Number 2 (2019), 217-39. 


\section{Emphasizing firmness over violence}

Through a set of designed curricula and religious activities, education in pesantren university is addressed to firmness in implementing self-discipline. Nevertheless, a firm attitude in practicing self-discipline does not lead students to violent acts. Instead of carrying out radical behavior, the three pesantren universities prioritize a wise attitude in Islamic proselytizing. Radicalism in the context of religious moderation is interpreted as an idea and understanding that wants to make a fundamental change to the social and political system instantly and violently in the name of religion. The keyword of radicalism is the emergence of attitudes and actions that want to change while conducting violent methods and opposing a prevailing legal system in a state.

Educational effort to avoid radicalism in pesantren university is conducted by instilling values of wisdom and democracy. Pesantren university prioritizes deliberation to interpret Jihad's deep meaning (holy war). Indeed, Islam has normative rules in the context of war, popularly known by the term 'jihad.' Nevertheless, Jihad is a multi-interpretative term; it has been interpreted variously by some Muslim scholars. ${ }^{21}$ Interpreting Jihad in a singular and rigid meaning only leads Islam to a monolithic essence and tends to a definition distortion. Therefore, Islamic education in pesantren university is through a rigid Islamic jurisprudence (figh) and instilling some values of wisdom and instilling a value of wisdom conducted in the teaching of Arabic words of wisdom (al-mahfiz $\bar{a} \bar{t}$ ).

Another way to reject radicalism and extremism in pesantren university is by conducting peace in a multicultural nuance of pesantren. Pesantren is a gathering place of many students with a different identity. This situation

\footnotetext{
${ }^{21}$ Moh Quraish Shihab, Tafsir Al-Mishbah: Pesan, Kesan dan Keserasian al-Qur'an, Jakarta: Lentera Hati, 2000; Ahmad Bazith, "Jihad dalam Perspektif Al-Qur'an”, Jurnal Tafsere, Vol. 2, No. 1 (2014), 67-94.
} 
creates a multicultural milieu. Students need to know each other sincerely to make an understanding of their social interaction. Cross-cultural and identity interaction should be well engaged through a depth of wisdom understanding around the university environment to create an active tolerance in responding to the multi-identity situation. Therefore, institutionally, the three pesantrens apply religious moderation values by avoiding violent action and the idea of religious extremism.

\section{Appreciating local culture}

Religious behaviors that accommodate local culture can see how religious practice could integrate with the local culture. Islam, on the one hand, has a nonnegotiable, principal teaching. However, Islam is revealed in the middle of cultured society in multicultural circumstances, on the other hand. Several Islamic values brought by the Prophet Muhammad always interact dialectically with an earlier cultural tradition. The Prophet Muhammad did not change the Arabic cultural tradition. Instead of changing the whole cultural tradition, the Prophet Muhammad adapted a cultural tradition philosophically with the Islamic norms. The example of the Prophet's appreciation of local culture could be seen from some religious practices conducted by Muslims, such as tawaf and aqiqah.

The three universities' pesantren system is not merely a place of religious education and training for students; the pesantren is designed and developed by a part of a cultured society close to the Indonesian culture. The three institutions have a variable pattern of different activities as an effort to appreciate cultural tradition. In Unida Gontor, for instance, a form of appreciation to cultural tradition is manifested by the art performing of Reog Ponorogo in every artistic event held annually. To keep well performed in cultural order, students invite art trainer for Reog from local people. Reog Ponorogo always enlivens students' festival as an appreciation 
of the local culture of Ponorogo, East Java, the place where Reog originated.

In other experience, pesantren at ma'had Aly As'adiyah has an appreciative way in local culture preservation. Pesantren As'adiyah places the Buginese language, especially in the educational field. Buginese language is taught formally as one of the academic courses. Students are also introduced to some classical Islamic books (Kitab Kuning) written by earlier Muslim scholars. Those classical books are translated into the Buginese language. The local wisdom of Buginese is also appreciated by holding a cultural, religious ritual called Barzanji. Barzanji is the popular name of one of several panegyrics of the Prophet Muhammad. The complete title of this panegyrics work is "Iqdu al-Jauhar fi Mawlidi al-Nabi al-Azhār" written by Ja'far bin Hasan al-Barzanji. The Barzanji is written in the Arabic language. As a form of appreciating local culture, pesantren As'adiyah Sengkang translated several poets of al-Barzanji into the Buginese language.

Several pesantren universities confirm that Islamic value transmission through traditional Islamic educational institutions is still relevant in the contemporary era. Globalization and modernization have increasingly freed public spaces to be discussed by various identities. Islamic proselytizing has shifted from traditional to modern institutions through online social media as a transmitter of Islamic values. Many instances of modern online Islamic proselytizing have often triggered the death of religious moderation attitudes due to some changes in religious authority. ${ }^{22}$ Mastery of classical

\footnotetext{
${ }^{22}$ Wahyudi Akmaliah, "The Demise of Moderate Islam: New Media, Contestation, and Reclaiming Religious Authorities," Indonesian Journal of Islam and Muslim Societies, Volume 10 , Number 1 (2020), 1-24. in which they do not engage a lot of this development of the digital platform. Consequently, dealing with religious issues, their voices become voiceless. By employing desk research through some relevant references and collecting information from social media, specifically Instagram and Youtube, this article examines the role of the Islamic organization of moderate Islam in the rapid of the digital platform as the new of the public sphere. The article finds that they have difference respond to dealing with the presence of the new religious authorities. In comparison, while Muhammadiyah is more accepting of them calmly, NU is more reactively in responding.Lanskap ruang publik Indonesia di tengah
} 
Islamic books is no longer an authoritative standard of Islamic preacher. Nowadays, Islamic preachers would meet with authority in a matter of their popularity. ${ }^{23}$ However, the pesantren university shows that traditional Islam still plays a positive role in social changes.

Through the origins, track records, and ideals, the three pesantren universities serve as a medium for internalizing Islamic values. This role continues to be realized through various academic and non-academic systematic efforts. Finally, the three pesantren universities play a role in strengthening several values of moderation in Islam through a designed curriculum applied to students' religious activities.

\section{Stay on the middle path}

This part emphasizes the unique characteristic of strengthening Islam's moderation from the pesantren universities. The three universities have a similar pattern in keeping authoritative traditional education system. A value of moderation in Islam is instilled through an eclectic curriculum designed through an Islamic education institution called pesantren. The curriculum character, implemented in the three universities, contains fundamental religious moderation values, such as fairness and balance. The moderate nature of this curriculum implementation is seen from a non-singular formula. The curriculum refers not only to one theory, source, and achievement but also to various sources. A variety of sources in the curriculum would create an eclectic curriculum character. The Eclectic curriculum applied in the three Pesantren universities illustrates inclusiveness in shaping student personality. Eclecticism is a school of

muncunya media sosial membuka kesempatan sekaligus ancaman terkait dengan dakwah Islam. Hal itu merupakan ancaman bagi dua organisasi besar Moderat Islam di Indonesia (Muhammadiyah dan NU

${ }^{23}$ Muzayyin Ahyar and Alfitri, "Aksi Bela Islam: Islamic Clicktivism and the New Authority of Religious Propaganda in the Millennial Age in Indonesia”, Indonesian Journal of Islam and Muslim Societies, Volume 19, Number 1 (2019): 1-29. 
philosophy that selects doctrines or thoughts to be applied to concrete actions. Initially, it was often associated with a derivative and a nonsystematic way of thinking. Therefore, this flow has a negative connotation that is consistently reflected in some reference resources. However, several post-modern studies show a positive side of eclecticism. It is the only way forward for philosophy after many steps of developments, in case it was not to keep retracing a succession of an obsolete system of thought. The essence of eclecticism is selecting truth against falsehood in the existing system as a strategic step to overcome the weaknesses and construct a superior alternative philosophy. ${ }^{24}$ Therefore, constructing an eclectic curriculum in the three pesantren universities is a form of open-mindedness in implementing moderate religious education.

The theory and practice of an eclectic curriculum that combine humanistic, social reconstruction, academic and technological courses show a strengthening of the religious moderation value. The humanistic curriculum is reflected in Pesantren's daily religious practices and the uswah of Kiai (exemplary scholar), murabbi, and Muallim (ustadz). As applied to the 3 Islamic universities, the eclectic Islamic boarding school curriculum shows that the universities instill national commitment, tolerance, antiviolence, and respect for local culture. However, moderation in Islam in the three universities has difference in program emphasizing. The emphasizing model occupies the three things: theoretical, practical, and ideological field. By those models of emphasizing religious moderation in Islam, the three pesantren universities stay in the middle path of Islamic schools.

The emphasizing of moderation in Islam in the theoretical field is more represented by UIN Maliki Malang than the two universities. Maulana

\footnotetext{
${ }^{24}$ The detailed explanation of eclecticism, see Myrto Hatzimichali, Potamo of Alexandria and the Emergence of Eclecticism in Late Hellenistic Philosophy, Cambridge: Cambridge University Press, 2011, 11; J. M. Dillon and A. A. Long, The Question of Eclecticism: Studies in Later Greek Philosophy, California: University of California Press, 2021.
} 
Malik Ibrahim university represents another state Islamic higher education institution that addresses the concept of religious moderation in a scientific study. UIN Maliki Malang places the concept of moderation in Islam as an object of research studied through some Islamic scientific instruments. The development of inter and multidisciplinary Islamic scholarship at UIN Maliki Malang has conceptualized the discourse of moderation in Islam by involving both religious sciences and non-religious sciences. In a practical field, Darussalam Gontor University plays an active role in strengthening the best practice of moderation in Islam through the pesantren system integrated with the higher education institution system. The togetherness of multicultural students within the scope of exclusive pesantren trains them to adapt several tolerance values. The institutional values of pesantren Gontor, which are taught continuously, make students close to Islam's spirit, nationality, and respect for local culture. The strict rules and discipline system in the pesantren would create students' mental and character to prioritize assertiveness over violence. All religious moderation practices are implemented in student life in pesantren without formal teaching of religious moderation theory.

Pesantren As'adiyah Sengkang has another unique character related to moderation in Islam. With an extensive network throughout all Indonesia regions, pesantren As'adiyah Sengkang keeps moderate behaviors ideologically. The organizational structure between the central organization and other branches of pesantren As'adiyah throughout Indonesia's regions makes it easy for this Educational Institution to control Islamic ideas relevant to the spirit of religious moderation. Another way of guarding Islamic ideology following the spirit of religious moderation is by instilling the institutional values of As'adiyah (ke-as'adiyah-an) in formal academic courses and other non-formal activities at university. These institutional values of As'adiyah become one of the unique characteristics in maintaining 
an attitude of moderation, especially in respect for local culture. By its name, As'adiyah is derived from its founder, Anregurutta HM As'ad. This Islamic Education Institution continues the idea of its founders in Islamic and cultural cogitation. The Sulawesi region Anregurutta H.M As'ad poses an integral combination between Islamic values and local culture in his proselytizing movement. The ideas of Anregurutta HM As'ad in broadcasting Islam were the institutional values in Ma'had Aly As'adiyah Sengkang.

\section{Conclusion}

One of Indonesia's Islamic universities' efforts in affirming the values of religious moderation is through a pesantren model applied to university students. Islamic boarding schools are formally institutionalized with distinctive organizational designs and curriculum models. The results of this study reveal that the three Islamic higher education institutions continue to maintain Islamic moderation values through campus boarding schools. The study's results reveal that the three Islamic higher education institutions continuously hold the middle path of Islam through pesantren university. The actualization of moderation in Islam is implemented through an eclectic curriculum, in which each institution has its character. The three pesantren universities have a distinctive difference in the emphasizing of moderation in Islam. The differences in the emphasizing of Islamic moderation are occupied in theoretical, practical, and ideological aspects. This article's findings theoretically imply several enriching studies on Indonesia's religious moderation, which becomes a unique characteristic of Islam in Indonesia. In practical terms, this study's results can be useful for policymakers-particularly those involved with religious policies-in making strategies for moderate cultivation of religious values through ideological, theoretical, and practical aspects, as what this article 
has revealed. Finally, like academic research, this article certainly needs a response from further studies that can generally examine these research findings. Further research could examine the article's results by placing it in some instances in various other Islamic education institutions. Therefore, studies on strengthening religious moderation in Indonesian Islamic Education Institutions are increasingly comprehensive and could be examined academically.

\section{Bibliography}

Ahyar, Muzayyin and Alfitri, "Aksi Bela Islam: Islamic Clicktivism and the New Authority of Religious Propaganda in the Millennial Age in Indonesia", Indonesian Journal of Islam and Muslim Societies, Volume 19, Number 1 (2019): 1-29.

Akmaliah, Wahyudi, "The Demise of Moderate Islam: New Media, Contestation, and Reclaiming Religious Authorities," Indonesian Journal of Islam and Muslim Societies, Volume 10, Number 1 (2020): 1-24.

Aslam, Mohd Mizan and Gunaratna, Rohan. Terrorist Rehabilitation and Community Engagement in Malaysia and Southeast Asia. London: Routledge, 2019.

Ayubi, Nazih. Political Islam: Religion and Politics in the Arab World. London: Routledge, 2003.

Bazith, Ahmad, "Jihad dalam Perspektif Al-Qur'an”, Jurnal Tafsere, Volume 2, Number 1, (2014): 67-94.

Bruinessen, Martin van. Kitab Kuning, Pesantren Dan Tarekat: Tradisi-Tradisi Islam di Indonesia. Bandung: Mizan, 1995.

Daniels, Timothy P. Sharia Dynamics: Islamic Law and Sociopolitical Processes. Switzerland: Palgrave MacMillan, Springer, 2017.

Davids, Nuraan, "Islam, Moderation, Radicalism, and Justly Balanced Communities," Journal of Muslim Minority Affairs, Volume 37, No. 3 (2017): 309-320.

Dillon, J. M. and Long, A. A. The Question of Eclecticism: Studies in Later Greek Philosophy. California: University of California Press, 2021.

Fealy, Greg and Barton, Greg. Nahdlatul Ulama, Traditional Islam and Modernity in Indonesia. Monash: Monash Asia Institute, Monash University, 1996.

Gabriel, Theodore and Smith. Jane Idleman, Islam and the West Post 9/11. London: Routledge, 2017. 
Gillum, Rachel M. Muslims in a Post-9/11 America. Michigan: University of Michigan Press, 2018.

Hamzah, Muchotob, et.al. Pengantar Studi Aswaja An-Nahdliyah. Yogyakarta: LKiS Pelangi Aksara, 2017.

Hatzimichali, Myrto. Potamo of Alexandria and the Emergence of Eclecticism in Late Hellenistic Philosophy. Cambridge: Cambridge University Press, 2011.

Hilmy, Masdar, "Quo-Vadis Islam Moderat Indonesia? Menimbang Kembali Modernisme Nahdlatul Ulama dan Muhammadiyah,” MIQOT: Jurnal IlmuIlmu Keislaman, Volume 36, Number 2 (2012): 262-281.

Islam, Tazul and Khatun, Amina, "Islamic Moderation in Perspectives: A Comparison Between Oriental and Occidental Scholarships," International Journal of Nusantara Islam, Volume 3, No. 2 (2015): 69-78.

Kamali, Mohammad Hashim. The Middle Path of Moderation in Islam: The Qur'anic Principle of Wasatiyyah. Oxford: Oxford University Press, 2015.

Lukens-Bull, Ronald, "Teaching Morality: Javanese Islamic Education in a Globalizing Era”, Journal of Arabic and Islamic Studies, Vol. 3, No. 1 (2000): 26-48.

Mahapatra, Chintamani. The US Approach to the Islamic World in Post-9/11 Era: Implications for India. New Delhi, Academic Foundation, 2009.

Nashir, Haedar. Understanding the Ideology of Muhammadiyah. Surakarta: Muhammadiyah University Press, 2015.

Nilan, Pam, "The Spirit of Education in Indonesian Pesantren," British Journal of Sociology of Education, Volume 30, No. 2 (2009): 219-232.

Pohl, Florian. Islamic Education, and the Public Sphere. Gottingen: Waxmann Verlag, 2009.

Prasojo, Zaenuddin Hudi, et.al, "Moderate Islam and the Social Construction of Multi-Ethnic Communities in the Hinterland of West Kalimantan," Indonesian Journal of Islam and Muslim Societies, Volume 9, Number 2 (2019): 217-239.

Qodir, Zuly. Muhammadiyah Studies: Reorientasi Gerakan dan Pemikiran Abad Kedua. Yogyakarta: Kanisius, 2010.

Sallabi, Ali Muhammad. Al-Wasatiiyyah fi al-Qur'>an al-Kari>m. Oman: Dar alNafais, 1999.

Shihab, Moh Quraish. Tafsir Al-Mishbah: Pesan, Kesan dan Keserasian al-Qur'an. Jakarta: Lentera Hati, 2000.

Suharto, Babun. Dari Pesantren Untuk Umat: Reinventing Eksitensi Pesantren Di Era Globalisasi, Surabaya: Imtiyaz, 2011. 
Keeping the middle path: mainstreaming religious moderation... (Muhammad Nasir, et.al)

The Center of Ma'had Al-Jami'ah. Pedoman Akademik Mahasantri Pusat Ma'had Al-Jami'ah 2019 Universitas Islam Negeri (UIN) Maulana Malik Ibrahim (Maliki) Malang. Malang: UIN Maulana Malik Ibrahim, 2019, 1.

Tim Penyusun. Moderasi Beragama. Jakarta: Badan Litbang dan Diklat Kementerian Agama RI, 2019.

Wajdi, Firdaus, "Pesantren and University: An Educational Networking in the Era of Globalization", Proceeding, International Conference on Social Science and Humanities in the Era of Market Globalization, Jakarta, 2018, Universitas Negeri Jakarta. 
